\title{
PERBEDAAN MODEL OHLSON, MODEL TAFFLER DAN MODEL SPRINGATE DALAM MEMPREDIKSI FINANCIAL DISTRESS
}

\author{
Anny Widiasmara ${ }^{1)}$,Henny Catur Rahayu ${ }^{2)}$ \\ Fakultas Ekonomi dan Bisnis Universitas PGRI Madiun \\ anny.asmara@gmail.com ${ }^{1}$, henny.leha@gmail.com²),
}

\begin{abstract}
The purpose of this study is to provide empirical evidence that there are differences in the Ohlson, the Taffler and the Springate Model in predicting financial distress for companies listed on the Indonesia Stock Exchange in 2015-2017. The population in this study are all nine industrial sector companies listed. This study uses secondary data from annual financial reports / annual report in 2015-2017. Testing the hypothesis in this study using the normality test and the Kruskal Wallis test (different test). The results showed that the Taffler model is the model that has the highest level of accuracy in predicting financial distress conditions of companies listed on the Stock Exchange with an accuracy rate of $83.93 \%$, then the Springate Model with an accuracy rate of $54.91 \%$ and the Ohlson Model which is a model with the lowest accuracy rate is $6.70 \%$.
\end{abstract}

Keywords: Ohlson Model, Taffler Model, Springate Model, Financial Distress

\section{Abstrak}

Tujuan dari penelitian ini adalah untuk memberikan bukti empiris bahwa terdapat perbedaan Model Ohlson, Model Taffler dan Model Springate dalam memprediksi financial distress perusahaan yang terdaftar di BEI tahun 2015-2017. Populasi dalam penelitian ini adalah semua perusahaan Sembilan sektor industri yang terdaftar di Bursa Efek Indonesia. Penelitian ini menggunakan data sekunder dari laporan keuanga tahunan/annual report pada 2015-2017. Pengujian hipotesis dalam penelitian ini menggunakan uji normalitas dan uji kruskal wallis (uji beda). Hasil penelitian menunjukkan bahwa model Taffler adalah model yang memliki tingkat akurasi tertinggi dalam memprediksi kondisi financial distress perusahaan-perusahaan yang terdaftar di BEI dengan tingkat akurasi 83,93\%, kemudian Model Springate dengan tingkat akurasi 54,91\% dan Model Ohlson yang merupakan model dengan tingkat akurasi paling rendah yaitu $6,70 \%$.

Kata Kunci: Ohlson, Taffler, Springate, Financial Distress

\section{PENDAHULUAN}

Kemampuan bisnis suatu perusahaan dipengaruhi oleh faktor berbeda. Faktor-faktor ini dikelompokkan sebagai manajerial, ekonomi, politik, dan lingkungan. Faktor-faktor tersebut harus diidentifikasi untuk mempertahankan penciptaan nilai dan kelangsungan hidup perusahaan. Meskipun ada banyak faktor eksternal yang sulit untuk dianalisis karena masalah pengukuran, salah satu opsi untuk membantu perusahaan dalam merencanakan operasi di masa depan adalah dengan melakukan analisis keuangan berdasarkan laporan keuangan dan rasio keuangan (Oz dan Yelkenci, 2015).
Setiap perusahaan didirikan dengan tujuan untuk menghasilkan keuntungan yang banyak sehingga mampu bertahan atau berkembang dalam jangka panjang. Namun, dalam kenyataannya banyak beberapa perusahaan yang mampu bertahan. Seringkali perusahaan sudah beroperasi dalam jangka waktu satu sampai dua tahun terpaksa gulung tikar karena mengalami financial distress dan berujung bangkrut. Analisis mengenai gejala-gejala kebangkrutan harus dilakukan, untuk mencegah terjadinya kebangkrutan di masa datang. Cara yang dapat dilakukan adalah dengan menganalisis rasio keuangan perusahaan dengan model tertentu. Hal ini mengingat 
banyak perusahaan-perusahaan di Indonesia yang mengalami kebangkrutan.

Pada tahun 2018 banyak perusahaan legendaris yang bangkrut karena mengalami kesulitan keuangan atau financial distress. Pada masa kejayannya perusahaan ini mampu menguasai pasar Indonesia. Hal ini dikarenakan sebagian besar konsumen tertarik dengan produk yang dihasilkan. Namun seiring berjalannya waktu, produk mereka sudah mulai tidak beroperasi di pasaran. Mereka tiba-tiba mengalami kebangkrutan yang tak terduga.

Dikutip oleh tribunnews.com kabar mengejutkan dari perusahaan teh merek Sariwangi. Dalam pertimbangannya, hakim Pengadila Niaga Jakarta Pusat menyatakan bahwa Sariwangi dan Indorub telah terbukti lalai menjalankan kewajibannya sesuai rencana perdamaian dalam proses Penundaan Kewajiban Pembayaran Utang (PKPU) terdahulu. "Mengabulkan permohonan pembatalan perdamaian atau homologasi dari pemohon (ICBC), menyatakan perjanjian homologasi batal, menyatakan termohon 1 (Sariwangi), dan termohon 2 (Indorub) pailit dengan segala akibat hukumnya," kata Majelis Hakim, Abdul Kohar saat membacakan amar putusan, selasa (16/10/2018) di Pengadilan Niaga Jakarta Pusat www.tribunnews.com

Beberapa perusahaan lain dengan merek yang populer di masyarakat juga mengalami kebangkrutan karena terlilit utang. Perusahaan tersebut adalah pabrik jamu legendaris Nyonya Meneer, Batavia Air, dan Amplop Jaya. Perusahaan tersebut bangkrut karena mengalami financial distress sehingga tidak bisa membayar utang-utangnya kepada bank. Setiap perusahaan harus mewaspadai adanyapotensi kebangkrutan, oleh karena itu perusahaan harus melakukan analisis yang berkaitan dengan kebangkrutan www.tribun-bali.com

Beberapa indikator yang digunakan untuk mengetahui kemungkinan dari kesulitan keuangan (financial distress), menurut Romadhona (2013) indikator tersebut, diantaranya :

1. Analisis arus kas periode sekarang dan periode yang akan datang.

2. Analisis strategi yang dilakukan perusahaan dengan cara mempertimbangkan pesaing potensial, struktur biaya relatif, perluasan rencana dalam industri, kemampuan perusahaan untuk menaikkan biaya, kualitas manajemen dan lain sebagainya.

3. Analisis laporan keuangan perusahaan disertai dengan perbandingan laporan keuangan dari perusahaan lain. Analisis berfokus pada suatu variabel keuangan tunggal atau suatu kombinasi dari variabel keuangan.

4. Variabel eksternal seperti pengembalian dari sekuritas dan penilaian obligasi.

Kebangkrutan adalah teka-teki yang coba dihindari oleh perusahaan, para analis suka mengukur dan menemukan kesulitan untuk memprediksi secara umum. Bahaya potensial dari tindakan semacam itu terletak pada aspek-aspek seperti kualitas aset yang buruk dan kapitalisasi yang lemah (Gosh, 2017). Memprakirakan setiap kekurangan dalam situasi keuangan perusahaan sangat berguna bagi investor di perusahaanperusahaan ini karena mereka akan menghindari kerugian dan untuk pelanggan mereka karena persediaan tidak lagi ada karena kebangkrutan. Kesulitan keuangan perusahaan dapat dipicu oleh faktor internal dan eksternal. Faktor internal dapat muncul dari manajemen 
yang tidak efisien yang akan mempengaruhi kinerja keuangan dan pengelolaan aset perusahaan dan sebagai hasilnya pendapatan yang dihasilkan tidak mencakup biaya. Faktor eksternal dapat berasal dari perubahan kondisi ekonomi di mana perusahaan beroperasi seperti inflasi, peraturan baru, dan sebagainya (Alali M.S et al, 2018).

Berbagai metode analisis telah dikembangkan untuk memprediksi kondisi financial distress suatu perusahaan diantaranya adalah yang dikembangkan oleh Springate (1978), Ohlson (1980) dan Taffler (1983). Pada penelitian yang dilakukan oleh Meiliawati \& Isharijadi (2016), model Springate merupakan model terakurat dalam memprediksi kondisi financial distress pada perusahaan sektor kosmetik yang terdaftar di BEI dengan tingkat akurasi 91,66\%, dibandingkan dengan model Altman dengan tingkat akurasi hanya $60,41 \%$.

Pada penelitian lain yang dilakukan oleh Priambodo (2017) yang berjudul Analisis Model Altman, Springate, Grover dan Zmijewski dalam Memprediksi Financial Distress pada Perusahaan Sektor Pertambangan. Hasii dari penelitian ini adalah model Springate merupakan model dengan tingkat akurasi tertinggi dibandingkan model prediksi lainnya yaitu $84,21 \%$.

Berbeda dengan penelitian yang dilakukan oleh Kusuma (2017) pada perusahaan sektor pertambangan batubara, menyatakan bahwa model Ohlson merupakan model terbaik dengan nilai akurasi tertinggi yaitu $100 \%$ dibandingkan model yang lainnya. Taffler (1983) merumuskan model prediksi kebangkrutan untuk perusahaan manufaktur dengan akurasi prediksi $95,7 \%$ untuk yang bangkrut dan $100 \%$ untuk perusahaan yang tidak bangkrut (Sayari, 2017).
Hasil penelitian penelitian yang dilakukan Perwira (2016) menujukkan bahwa model Taffler merupakan model yang paling tepat untuk memprediksi kondisi bankcrupty dengan nilai akurasi $71 \%$. Dibandingkan dengan model lain yaitu Springate dan Kida memiliki tingkat akurasi $65 \%$, Altman tingkat akurasi $41 \%$. Penelitian ini dilakukan pada perusahaan sub sektor tekstil dan garmen yang terdaftar di BEI periode 2011-2015.

Berdasarkan rumusan masalah yang telah disampaikan, tujuan dalam penelitian ini adalah :Untuk menguji secara empiris perbedaan model Ohlson, model Taffler dan model Springate dalam memprediksi kondisi financial distress perusahaan-perusahaan yang terdaftar di Bursa Efek Indonesia periode 2015-2017.

\section{KAJIAN TEORI DAN PENGEMBANGAN HIPOTESA Analisis Laporan Keuangan}

Laporan keuangan yang disajikan perusahaan bertujuan untuk menyediakan informasi tentang posisi keuangan, kinerja keuangan, serta perubahan posisi keuangan yang bermanfaat dalam proses mengambil keputusan secara ekonomi bagi penggunanya. Laporan tahunan adalah laporan yang disampaikan selama satu periode oleh manajemen perusahaan kepada para investor (Margaretha, 2011). Laporan tahunan atau annual report terdiri atas informasi verbal dan informasi kuantitatif. Informasi verbal berisi opini manajemen atas operasi tahun lalu dan prospek di masa datang. Informasi kuantitatif berisi laporan keuangan.

Laporan keuangan adalah laporan yang memberikan gambaran posisi keuangan perusahaan. Laporan keuangan terdiri dari :

a. Laporan Laba/Rugi, berisi tentang laporan pendapatan-pendapatan 
dan biaya-biaya perusahaan selama satu periode.

b. Laporan Neraca, berisi laporan keadaan aktiva, utang dan modal sendiri perusahaan selama satu periode.

c. Laporan Saldo Laba, berisi laporan tentang laba yang dihasilkan dan akan dibagikan sebagai deviden.

d. Laporan Arus Kas, berisi laporan atas dampak kegiatan operasi, investasi dan pembiayaan perusahaan terhadap arus kas selama satu periode

Analisis rasio keuangan adalah rasio yang diperoleh dengan menghubungkan satu pos laporan keuangan dengan pos lainnya yang memiliki hubungan relevan dan signifikan (Yuliastary \& Wirakusuma, 2014). Menurut Keown, et al (2011) rasio keuangan membantu mengidentifikasi kelemahan dan kekuatan keuangan perusahaan. Terdapat dua cara membandingkan data keuangan perusahaan, pertama meneliti rasio antar waktu untuk meneliti arah pergerakannya. Kedua membandingkan rasio perusahaan dengan rasio perusahaan lainnya.

\section{Model Analisis Kebangkrutan}

\section{Model Ohlson}

James Ohlson mengemukakan model analisa kebangkrutan yang dilakukan pada penelitiannya pada tahun 1980. Dalam penelitian Ohlson pada tahun 1970-1976, dengan sampel 105 perusahaan bangkrut dan 2.058 perusahaan tidak bangkrut. Untuk pertama kalinya, menerapkan model logit bersyarat ke studi prediksi default. Manfaat praktis dari metodologi logit adalah bahwa mereka tidak memerlukan asumsi pembatasan MDA dan memungkinkan bekerja dengan sampel yang tidak proporsional. Setelah Ohlson, sebagian besar literatur akademik menggunakan model logit untuk memprediksi default (Plihal et al, 2018). Ohlson menggunakan logistic regression dalam model analisisnya dikarenakan Ohlson mencoba untuk mengatasi kelemahan dari penggunaan model MDA (Multiple Discriminant Analysis). MDA adalah teknik analisis yang paling populer untuk studi kebangkrutan, namun menurut Ohlson MDA mempunyai permasalahan seperti adanya persyaratan statistik tertentu yang dikenakan pada bagian distribusi prediktor (Utama, 2018).

Ohlson memilih sembilan variabel independen yang menurutnya harus membantu dalam memprediksi kebangkrutan, tetapi tidak memberikan justifikasi teoretis untuk seleksi (Jouzbarkand et al, 2012). Model yang dikemukakan oleh Ohlson memiliki 9 variabel rasio keuangan, yaitu :

\section{O Score $=-1,32-0,407 \times 1+6,03 \times 2-1,43 X 3+0,0757 X 4-2,37 X 5-$ $1,83 \times 6+0,285 \times 7-1,72 \times 8-0,521 \times 9$}

Keterangan :

X1 : Log (total aset/indeks tingkat harga GNP)

$\mathrm{X} 2$ : Total utang/total aset
X3 : Modal kerja/total aset

$\mathrm{X} 4$ : Utang lancar/aktiva lancar

X5 : 1 jika total utang > total aset, 0 jika total utang $<$ total aset 
X6 : Laba bersih/total aktiva

X7 : Arus kas operasi/total utang

X8 : 1 jika laba bersih negatif (-) untuk 2 tahun terahir, 0 jika laba bersih positif $(+)$ untuk 2

tahun terakhir

X9 : (laba bersih tahun $_{\mathrm{t}}$ - laba bersih tahun $\left._{\mathrm{t}-1}\right) /\left(\right.$ laba bersih tahun $_{\mathrm{t}}+$ laba bersih $\left.\operatorname{tahun}_{\mathrm{t}-1}\right)$

Dalam penelitian yang dilakukan Kusuma (2017) klasifikasi perusahaan yang sehat dan bangkrut yang didasarkan pada model Ohlson yaitu :

a. Jika O-score $<0,38$ artinya perusahaan sehat secara keuangan

b. Jika O-score $\geq 0,38$ maka perusahaan termasuk dalam klasifikasi perusahaan tidak sehat.
Model Taffler

Taffler (1983) merumuskan model prediksi kebangkrutan untuk perusahaan manufaktur yang dikutip di London Bursa Efek periode 1969-1976. Terdapat 4 variabel yang digunakan dalam penelitian ini dan Taffler menggunakan teknik analisis MDA dengan akurasi prediksi 95,7\% untuk yang bangkrut dan $100 \%$ untuk perusahaan yang tidak bangkrut (Sayari, 2017).

Model yang dikemukakan oleh Taffler adalah

$$
Z_{\text {Taffler }}=3,20+12,18 X 1+2,50 X 2-10,68 X 3+0,0289 X 4
$$

Keterangan :

X1 : Laba sebelum pajak/kewajiban lancar

X2 : Aktiva Lancar/Total Kewajiban

X3 : Kewajiban Lancar/Total Aktiva

X4 : Laba bersih setelah pajak/total aktiva

Jika nilai Taffler negatif maka perusahaan beresiko bangkrut, sedangkan jika nilai Taffler positif maka perusahaan tidak beresiko bangkrut. Dalam model Taffler ini jika nilai Taffler > 0,3 maka resiko bangkrut rendah, jika nilai Taffler < 0,2 maka resiko bangkrut tinggi (Perwira, 2016).

$$
\mathrm{S}=1,03 \mathrm{X} 1+3,07 \mathrm{X} 2+0,66 \mathrm{X} 3+0,4 \mathrm{X} 4
$$

Keterangan :

X1 : Modal Kerja/Total Aset

X2 : Laba Sebelum Pajak/Total Aset

X3 : Laba Sebelum Pajak/Kewajiban Lancar

X4 : Penjualan/Total Aset

Pada penelitian yang dilakukan

oleh Zeynep \& Erdem (2017) yang

\section{Model Springate}

Springate (1978) mengemukakan model analisis kebangkrutan dengan teknik analisis MDA. Model Springate menggunakan empat rasio yang dapat digunakan untuk mengukur kondisi perusahaan yang mengalami distress dan yang tidak distress (Hariani \& Sujianto, 2017).

Model yang dekemukakan oleh Springate adalah :

dilakukan di Turki dengan judul Financial Failure Estimate in BIST Companies with Altman (Z-Score) and Springate (S-Score) Models, jika nilai Springate $<0,862$ diperkirakan perusahaan akan bangkrut atau tidak sehat. Berarti sebaliknya jika nilai Springate > 0,862 diperkirakan perusahaan dalam kondisi sehat. 


\section{Financial Distress}

Financial distress sebagai tahap penurunan kondisi keuangan yang terjadi sebelum terjadinya kebangkrutan atau likuiditasi. Financial distress dimulai dari ketidakmampuan dalam memenuhi kewajiban-kewajibannya, terutama kewajiban yang bersifat jangka pendek termasuk kewajiban likuidaitas, dan juga termasuk kewajiban dalam kategori solvabilitas (Fahmi, 2013).

Sebuah perusahaan tidak akan mengalami kebangkrutan secara tiba-tiba, namun dalam proses waktu yang berlangsung lama, dan itu dapat dilihat dari tanda-tanda. Pada saat ini beberapa model telah dikembangkan untuk memprediksi tanda-tanda terjadinya kebangkrutan. Financial distress mengacu pada kondisi di mana perusahaan tidak dapat memenuhi, atau mengalami kesulitan melunasi, kewajiban keuangan kepada kreditornya, biasanya karena biaya tetap yang tinggi, tidak likuid aset, atau pendapatan yang peka terhadap penurunan ekonomi (Indriyanti, 2019).

Menurut Fahmi (2013) secara kajian umum ada 4 kategori penggolongan financial distress yaitu :

a. Financial distress kategori A atau sangat tinggi dan benar-benar membahayakan. Kategori ini memungkinkan perusahaan dinyatakan bangkrut. Kategori ini memungkinkan pihak perusahaan melaporkan kepada pihak pengadilan bahwa perusahaan dalam posisi bangkrut dan menyerahkan berbagai urusan untuk ditangani oleh pihak luar perusahaan. b. Financial distress kategori B atau tinggi dan dianggap berbahaya. Pada posisi ini perysahaan harus memikirkan berbagai solusi untuk menyelamatkan beragai aset yang dimiliki. Termasuk memikirkan dampak apabila mengambil keputusan untuk merger dan akuisis. Salah satu dampak yang terlihat pada posisi ini adalah PHK (Pemutusan Hubungan Kerja) dan pensiun dini padabeberapa karyawan.

c. Financial distress kategori $\mathrm{C}$ atau sedang dan dianggap perusahaan masih mampu menyelamatkan diri dengan tindakan tambahan dana yang bersumber dari internal maupun eksternal. Pada posisi ini perusahaan sudah harus melakukan perombakan berbagai kebijakan dan konsep manajemen. Jika perlu perusahaan melakukan perektrutan tenaga ahli yang berkompeten tinggi untuk ditempatkan pada posisi yang bertugas menyelamatkan perusahaan, termasuk target dalam menggenjot perolehan laba kembali.

d. Financial distress kategori D atau rendah. Pada posisi ini perusahaan dianggap hanya mengalami fluktuasi finansial temporer yang disebabkan oleh berbagai kondisi eksternal dan internal. Biasanya kondisi ini bersifat jangka pendek sehingga kondisi ini bisa cepat diatasi.

Keputusan menyelesaikan masalah financial distress bisa dilakukan dengan menjual obligasi atau menerbitkan saham baru, meminjam dana ke bank atau 
menerbitkan right issue. Right issue adalah penjualan saham terbatas yang hanya dikhususkan kepada pemilik saham lama saja, dengan tujuan menghindari masuknya pemilik saham baru.

Beberapa indikator digunakan untuk memprediksi kebangkrutan, yaitu dari dalam perusahaan (indikator internal) dan dari luar perusahaan (indikator eksternal). Indikator internal misalnya laporan keuangan, aliran kas, kemampuan manajemen dan trend penjualan. Indikator eksternal bisa dilihat dari pasar keuangan, informasi dari pemasok dan konsumen (Hanafi, 2016). Apabila jumlah aktiva lebih kecil dari jumah hutang dan modal kerja yang negatif sehingga menyebabkan perusahan terus merugi maka kondisi tersebut dapat dikatakan perusahaan mengalami kondisi financial distress (Khoiriyah, 2019).

Menurut Hanafi (2016) jika perusahaan mengalami financial distress atau kesulitan keuangan, ada dua pilihan alternatif untuk mengatasi hal tersebut yaitu dengan melakukan likuidasi atau reorganisasi. Dilakukan likuidasi jika nilai likuidasi lebih besar dibandingkan dengan nilai perusahaan kalau diteruskan. Reorganisasi dilakukan jika perusahaan masih menunjukkan prospek yang baik, sehingga nilai perusahaan kalau diteruskan lebih besar dibandingkan dengan apabila perusahaan dilikuidasi.

Penelitian ini bertujuan untuk menguji ketiga model prediksi financial distress yaitu model Ohlson, model Taffler dan model Springate. Sehingga hasil dari penelitian ini adalah menentukan model mana yang paling baik dengan tingkat akurasi yang paling tinggi.
Penelitian yang dilakukan Kusuma (2017) menunjukkan hasil bahwa model Ohlson memiliki nilai akurasi tertinggi dibandingkan dengan model Altman, Springate, Zmijewski dan Grover. Pada penelitian Perwira (2016) tingkat akurasi tertinggi dimiliki oleh model Taffler, studi kasus pada perusahaan sub sektor tekstil dan garmen.

Analisis Potensi Kebangkrutan dengan Menggunakan Model Altman ZScore, Springate dan Zmijewski Pada Industri Perdagangan Ritel yang Terdaftar di BEI tahun 2009-2013 adalah penelitian yang dilakukan Sondakh, dkk (2014). Hasil dari penelitian tersebut adalah model Springate memiliki tingkat keakuratan lebih tinggi dibandingkan dengan model yang lainnya. Pada penelitian Priambodo (2017) pada perusahaan sektor pertambangan yang menggunakan model Altman, Springate, Grover dan Zmijewski menyatakan bahwa model Springate memiliki tingkat akurasi tertinggi.

Berdasarkan beberapa penelitian terdahulu yang telah dikemukanan, maka hipotesis yang diajukan dalam penelitian ini adalah:

$\mathrm{H}_{1}$ : Model Springate merupakan model yang tingkat akurasinya paling tinggi dan merupakan model yang terbaik.

\section{METODE PENELITIAN}

Penelitian ini dilakukan pada sembilan sektor industri yang terdaftar di BEI (Bursa efek Indonesia). Sumber data diperoleh dari situs website www.idx.co.id. Desain penelitian adalah rancangan penelitian yang berfungsi sebagai pedoman dalam proses penelitian. Desain dalam penelitian ini berasal dari 
rumusan masalah. Rumusan masalah dinyatakan dalam kalimat pertanyaan, kemudian peneliti menggunakan teori untuk menjawabnya. Data yang diperoleh dalam penelitian ini adalah data sekunder yang diperoleh dari data laporan keuangan tahunan perusahaan yang terdaftar di BEI tahun 2016-2017. Penelitian ini

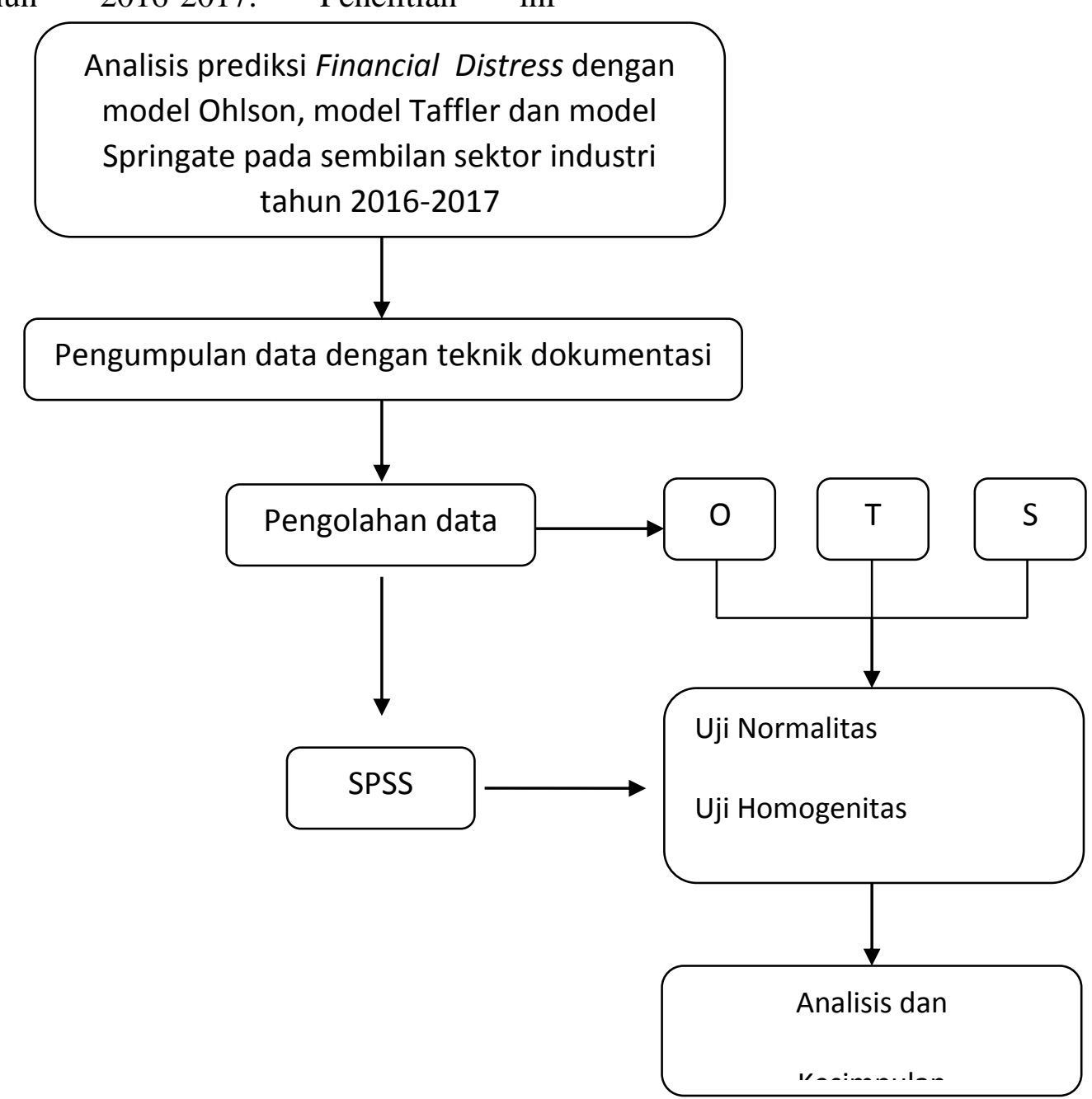

Gambar 1. Desain Penelitian

Dalam penelitian ini, teknik pengambilan sample yang dilakukan adalah teknik purposive sampling, dimana dimaksudkan untuk menganalisis prediksi kondisi financial distress dengan model Ohlson, Taffler dan Springate periode penelitian penelitian tahun 2016-2017 dan model manakah yang terbaik yang digunakan dalam memprediksi kondisi financial distress. 


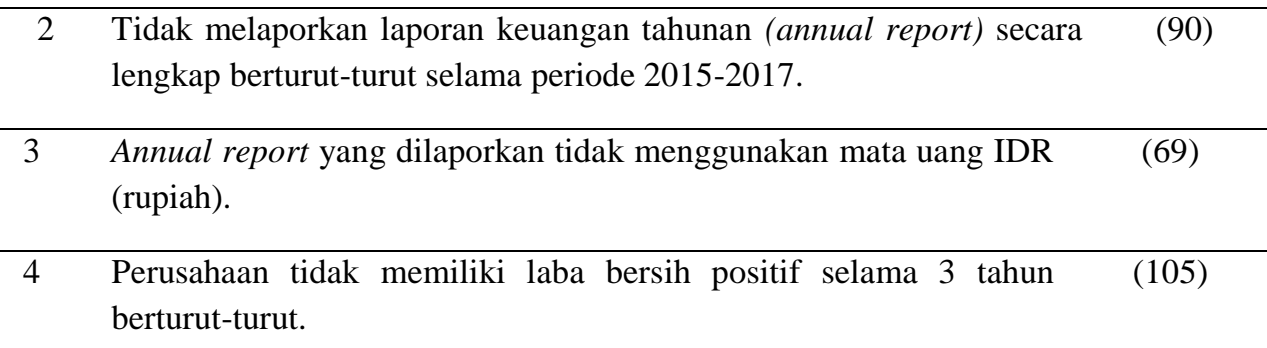

\begin{tabular}{ll}
\hline Jumlah & 224 \\
\hline
\end{tabular}

Data yang digunakan adalah data sekunder berupa laporan keuangan tahunan/annual report periode 2016-2017 yang dipublikasikan oleh perusahaan di website BEI (Bursa Efek Indonesia). Teknik yang digunakan untuk mendapatkan data yang diperukan dalam penelitian ini adalah :

1. Studi pustaka, dengan melakukan kajian pada sumber - sumber bacaan dan jurnal - jurnal penelitian yang berkaitan dengan masalah yang akan diteliti yang digunakan sebagai pedoman teori.

2. Teknik dokumentasi, yaitu dengan mengumpulkan data berupa laporan keuangan tahunan / annual report perusahaan dan diseleksi untuk diolah dalam penelitian ini.

Menurut Sugiyono (2016) kegiatan dalam analisis data adalah mengelompokkan data berdasarkan variabel dan jenis responden, mentabulasi data berdasarkan variabel dari seluruh responden, menyajikan data tiap variabel yang diteliti, melakukan perhitungan untuk menjwab rumusan masalah, dan melakukan perhitungan untuk menguji hipotesis yang telah diajukan. Untuk menjawab rumusan masalah, maka dilakukan teknik analisis data sebagai berikut :
1. Menghitung kondisi kebangkrutan masing - masing model :

a. Model Ohlson

b. Model Taffler

c. Model Springate

2. Menentukan kondisi kebangkrutan

a. Model Ohlson

Jika O-score < 0,38 artinya perusahaan sehat secara keuangan Jika O-score $\geq 0,38$ maka perusahaan termasuk dalam klasifikasi perusahaan tidak sehat.

b. Model Taffler

Jika nilai Taffler > 0,3 maka resiko bangkrut rendah

Jika nilai Taffler $<0,2$ maka resiko bangkrut tinggi

c. Model Springate Jika nilai Springate > 0,862 maka perusahaan masuk kategori sehat.

Jika nilai Springate $<0,862$ maka perusahaan masuk kategori tidak sehat atau berpotensi bangkrut.

3. Uji hipotesis dengan menggunaan SPSS

\section{Data Normal}

a. Uji Normalitas

Uji normalitas digunakan untuk 
menguji apakah dalam model regresi, variabel memiliki distribusi normal (Ghozali, 2016). Jika analisis menggunakan metode parametrik, maka persyaratan normalitas harus terpenuhi yaitu data harus berdistribusi normal. Jika data tidak berdistribusi normal maka metode yang digunakan adalah non parametrik. Dalam penelitian ini akan digunakan uji statistik One Sample Kolmogorov Smirnov dengan menggunakan taraf signifikan 0,5 . Data yang memiliki taraf signifikan lebih dari 0,5 maka data tersebut berdistribusi normal.

b. Uji Homogenitas

Uji homogenitas digunakan untuk menguji apakah dalam model regresi, variabel memiliki distribusi homogen atau tidak (Ghozali, 2016). Data yang baik yaitu data harus berdistribusi homogen. Pengambilan data didasarkan pada nilai signifikasi probabilitas. Data yang memiliki taraf signifikan lebih dari 0,5 maka data tersebut berdistribusi homogen.

c. Uji One Way ANOVA (uji beda)

\section{HASIL DAN PEMBAHASAN}

\section{Pengujian Hipotesis}

\section{Uji Kruskal Wallis}

Uji Kruskal Wallis merupakan uji yang dilakukan sebagai alternatif dari uji One Way ANNOVA. Karena data tidak berdistribusi normal maka Uji One Way

\begin{abstract}
Analysis of variance (ANOVA) adalah salah satu metode untuk menguji hubungan antara satu variabel dependen dengan satu atau lebih variabel independen (Gozhali, 2016). One Way ANOVA digunakan untuk mengetahui perbandingan model Ohlson, Taffler dan Springate dalam memprediksi kondisi financial distress pada sembilan sektor industri perusahaan yang terdaftar di BEI.
\end{abstract}

\section{Data Tidak Normal}

a. Uji Kruskal Wallis

Uji Kruskal Wallis adalah uji statistik yang digunakan untuk mempelajari perbedaan rata-rata lebih dari dua variabel. Uji Kruskal Wallis dapat dignakan sebagai alternatif uji One Way ANOVA apabila data penelitian dalam skala ordinal. Uji Kruskal Wallis tidak memerlukan asumsi normal dan homogen pada distribusi data (Kadir, 2015).

ANNOVA tidak dapat dilanjutkan, sehingga menggunakan Uji Kruskal Wallis. Pengambilan keputusan dalam uji ini adalah jika nilai Asymp.Sig > 0,05 maka tidak ada perbedaan, sebaliknya jika nilai Asymp.Sig $<0,05$ maka terdapat perbedaan.

Tabel 2. Hasil uji Kruskal Wallis adalah sebagai berikut : 


\section{Ranks}

\begin{tabular}{|cl|c|c|}
\hline \multicolumn{2}{|c|}{ MODEL } & $\mathrm{N}$ & Mean Rank \\
\hline PREDIKSI & OHLSON & 672 & 1061.62 \\
& TAFFLER & 672 & 1351.82 \\
& SPRINGATE & 672 & 612.06 \\
& Total & 2016 & \\
\hline
\end{tabular}

Test Statistics ${ }^{a, b}$

\begin{tabular}{|l|r|}
\hline & PREDIKSI \\
\hline Chi-Square & 551.028 \\
Df & 2 \\
Asymp. Sig. & .000 \\
\hline
\end{tabular}

a. Kruskal Wallis Test

b. Grouping Variable: MODEL

Berdasarkan hasil uji Kruskal Wallis di atas terlihat bahwa output Test Statistic diketahui nilai Asymp.Sig sebesar 0,000 < 0,05. Maka dapat disimpulkan bahwa terdapat perbedaan yang signifikan antara ketiga Model prediksi financial distress.
Perbandingan Hasil Analisis Prediksi Model Ohlson, Model Taffler dan Model Springate

Dari hasil perhitungan ketiga model prediksi yaitu model Ohlson, model Taffler dan model Springate dapat diketahui jumlah perusahaan yang sehat dan tidak sehat pada masing-masing model. Berikut sampel yang diprediksi sehat dan tidak sehat

Tabel 3. Rekapitulasi Hasil Perhitungan Model Ohlson, Model Taffler dan Model Springate

\begin{tabular}{|c|c|c|c|}
\hline Model & Sehat & Tidak Sehat & Jumlah \\
\hline Ohlson & 15 & 209 & 224 \\
\hline Tafller & 188 & 36 & 224 \\
\hline Springate & 123 & 101 & 224 \\
\hline
\end{tabular}

Sumber: Data Diolah

Dari hasil perhitungan model prediksi dalam tabel diatas, dapat diketahui bahwa
1. Model Ohlson menyatakan 15 perusahaan dalam kondisi sehat dan 209 perusahaan dalam kondisi 
tidak sehat.

2. Model Taffler menyatakan 188 perusahaan dalam kondisi sehat dan 36 perusahaan dalam kondisi tidak sehat.

3. Model Springate menyatakan 123 perusahaan dalam kondisi sehat dan 101 perusahaan dalam kondisi tidak sehat.

\section{Hasil Perhitungan Tingkat Akurasi dan Tipe Eror}

Setelah dilakukan perhitungan model prediksi dengan keadaan perusahaan, selanjutnya menghitung tingkat akurasi dan tiper eror. Tingkat

$$
\begin{aligned}
\text { Tipe eror I } & =\frac{\text { jumlah kesalahan tipe eror I }}{\text { jumlah sampel }} \times 100 \% \\
\text { Tipe eror II } & =\frac{\text { jumlah kesalahan tipe eror II }}{\text { jumlah sampel }} \times 100 \%
\end{aligned}
$$

Untuk mengetahui tingkat akurasi dan tipe dari masing-masing model prediksi. eror model Ohlson, model Taffler dan model Springate, berikut hasil perhitungan

\begin{tabular}{|c|c|c|c|c|c|c|c|}
\hline \multirow{2}{*}{\multicolumn{2}{|c|}{ REKAP }} & \multicolumn{2}{|c|}{ Ohlson } & \multicolumn{2}{|c|}{ Taffler } & \multicolumn{2}{|c|}{ Springate } \\
\hline & & Sehat & Tidak & Sehat & Tidak & Sehat & Tidak \\
\hline \multirow{2}{*}{ Riil } & Sehat & 15 & 209 & 188 & 36 & 123 & 101 \\
\hline & $\begin{array}{l}\text { Tidak } \\
\text { Sehat }\end{array}$ & 0 & 0 & 0 & 0 & 0 & 0 \\
\hline \multicolumn{2}{|c|}{ Tingkat Akurasi } & \multicolumn{2}{|c|}{$6,70 \%$} & \multicolumn{2}{|c|}{$83,93 \%$} & \multicolumn{2}{|c|}{$54,91 \%$} \\
\hline \multicolumn{2}{|c|}{ Tipe Eror I } & \multicolumn{2}{|c|}{$93,30 \%$} & \multicolumn{2}{|c|}{$16,07 \%$} & \multicolumn{2}{|c|}{$45,09 \%$} \\
\hline \multicolumn{2}{|c|}{ Tipe Eror II } & \multicolumn{2}{|c|}{0} & \multicolumn{2}{|c|}{0} & \multicolumn{2}{|c|}{0} \\
\hline
\end{tabular}

Tabel 4. Hasil Perhitungan Tingkat Akurasi dan Tipe Eror

Sumber: Data Diolah

Keadaan riil perusahaan dinyatakan "sehat" apabila memiliki laba bersih positif, sebaliknya perusahaan dinyatakan "tidak sehat" apabila memiliki laba bersih akurasi digunakan untuk mengetahui tingkat ketepatan model dengan melihat nilai tipe eror dari masing-masing model (Hasanah, 2010). Tingkat akurasi dihitung dengan rumus sebagai berikut:

$$
\begin{aligned}
& \text { Tingkat akurasi }= \\
& \frac{\text { jumlah prediksi benar }}{\text { jumlah sampel }} \times 100 \%
\end{aligned}
$$

Tiper eror dibagi menjadi 2 yaitu tipe eror I dan tipe eror II. Untuk tipe eror dihitung dengan rumus sebagai berikut: 
riil perusahaan dinyatakan sehat dengan ketiga model prediksi.

Dari tabel 4 dapat diketahui perbandingan hasil akurasi dan tipe eror dengan membandingkan hasil prediksi dengan kondisi riil perusahaan.

1. Model Ohlson memiliki tingkat akurasi sebesar $6,70 \%$ berdasarkan analisis yang dilakukan pada 224 perusahaan. Ketepatan analisis ini dapat dilihat dari 15 perusahaan yang dinyatakan sehat menurut hasil prediksi dan menurut kondisi perusahaan. Sedangkan tipe eror pada model Ohlson sebesar 93,30\% yang menyatakan 209 perusahaan mengalami kondisi tidak sehat namun faktanya kondisi perusahaan tersebut dalam kondisi sehat.

2. Model Taffler memiliki tingkat akurasi sebesar 83,93\% berdasarkan analisis yang dilakukan pada 224 perusahaan. Ketepatan analisis ini dapat dilihat dari 188 perusahaan yang dinyatakan sehat menurut hasil prediksi dan menurut kondisi perusahaan. Sedangkan tipe eror pada model Ohlson sebesar 16,07\% yang menyatakan 36 perusahaan mengalami kondisi tidak sehat namun faktanya kondisi perusahaan tersebut dalam kondisi sehat.
3. Model Springate memiliki tingkat akurasi sebesar $54,91 \%$ berdasarkan analisis yang dilakukan pada 224 perusahaan. Ketepatan analisis ini dapat dilihat dari 123 perusahaan yang dinyatakan sehat menurut hasil prediksi dan menurut kondisi perusahaan. Sedangkan tipe eror pada model Ohlson sebesar 45,09\% yang menyatakan 101 perusahaan mengalami kondisi tidak sehat namun faktanya kondisi perusahaan tersebut dalam kondisi sehat.

Berdasarkan hasil dari perhitungan model Ohlson, model Taffler dan model Springate dalam memprediksi kondisi financial distress menunjukkan bahwa terdapat perbedaan dari masing-masing model. Karena memang masing-masing model menggunakan variabel rasio yang berbeda-beda. Hasil analisis SPSS uji Kruskall Wallis juga menunjukkan bahwa terdapat perbedaan yang signifikan dari ketiga model prediksi tersebut.

Dari hasil perhitungan tingkat akurasi dan tipe eror maka dapat disampaikan perbedaan tingkat akurasi dan tipe eror dari setiap model. 


\begin{tabular}{|l|l|l|}
\hline Model & Tingkat Akurasi & Tipe Eror \\
\hline Ohlson & $6,70 \%$ & $93,30 \%$ \\
\hline Taffler & $83,93 \%$ & $16,07 \%$ \\
\hline Springate & $54,91 \%$ & $45,09 \%$ \\
\hline
\end{tabular}

Sumber: Data Diolah

Berdasarkan tabel di atas menunjukkan bahwa tingkat akurasi paling tinggi adalah model Taffler yaitu 83,93\% dengan tipe eror $16,70 \%$. Selanjutnya model Springate dengan tingkat akurasi $54,91 \%$ dengan tipe eror $45,09 \%$. Kemudian model yang paling rendah tingkat akurasinya adalah model Ohlson yaitu sebesar $6,70 \%$ dengan tipe eror 93,30\%. Maka dari model Ohlson, model Taffler dan model Springate dalam memprediksi kondisi financial distress pada sembilan sektor industri di BEI tahun 2015-2017, model terbaik adalah model Taffler.

Berdasarkan hasil penelitian ini maka hipotesis ditolak. Karena hasil dari penelitian ini menyatakn model Taffler merupakan model terbaik dengan tingkat akurasi paling tinggi. Hasil penelitian ini sesuai dengan hasil penelitian yang dilakukan Perwira (2016) yang menunjukkan bahwa model Taffler memiliki tingkat akurasi tertinggi dibandingkan dengan model Springate, model Kida dan model Altman yaitu 71\%. Hal tersebut serupa dengan model Ohlson yang merupakan model prediksi kebangkrutan dengan peringkat terendah yaitu $27,55 \%$. Hasil tersebut merupakan hasil penelitian dari Jayanti \& Rustiana (2015).

Hasil penelitian ini berbeda dengan penelitian yang dilakukan Wulandari, dkk
(2014), menunjukkan bahwa model Ohlson merupakan model yang paling efektif dan akurat dalam memprediksi kondisi financial distress perusahaan Food and Beverages di BEI tahun 2010-2012. Sedangkan dalam penelitian ini model Ohlson merupakan model yang memiliki tingkat akurasi paling rendah.

\section{KESIMPULAN DAN SARAN}

\section{Simpulan}

Berdasarkan hasil analisis data dan hasil uji hipotesis yang telah dilakukan maka dapat diambil kesimpulan bahwa terdapat perbedaan yang signifikan antara model Ohlson, model Taffler dan model Springate dalam memprediksi kondisi financial distress pada Sembilan sektor industri yang terdaftar di Bursa Efek Indonesia (BEI) tahun 2015-2017. Model yang terbaik dalam memprediksi financial distress dalam penelitian ini adalah model Taffler

\section{Saran}

1. Penelitian ini menunjukkan hasil prediksi kodisi perusahaan, sehingga para investor dapat menggunakannya sebagai pertimbangan dalam melakukan investasi pada perusahaan tertentu.

2. Untuk peneliti selanjutnya dapat menggunakan model prediksi yang 
lain dalam memprediksi kondisi financial distress.

\section{DAFTAR PUSTAKA}

Alali, M.S., Alawadhi, A.M., \& Bash, A.Y. (2018). Predicting Bankruptcy Risk For Healthcare Companies Listed in Kuwait Stock Exchange Using Altman's Z-Score Model. International Journal of Economics and Finance Research \& Applications, Vol 2, Issue 1. Kuwait.

Fahmi, I. (2013). Analisis Laporan Keuangan. Bandung; Penerbit Alfabeta.

Ghozali, I. (2016). Aplikasi Analisis Multivariete dengan program IBM SPSS 23. Semarang: Badan Penerbit Universitas Diponegoro.

Gosh, B. (2017). Bankruptcy Modelling of Indian Public Sector Banks: Evidence From Neural Trace. International Journal of Applied Behavioral Economics. Volume 6. Issue 2. India: Institute of Management Christ University.

Hanafi, M.M. (2016). Manajemen Keuangan Edisi 2. Yogyakarta: BPFE-Anggota IKAPI.

Hariani, D.S. \& Sujianto, A. (2017). Analisis Perbaandingan Model Altman, Model Springate dan Model Zmijewski dalam Memprediksi Kebangkrutan
Bank Syariah di Indonesia. Inventory Jurnal Akuntansi, Vol 1. Madiun: Program Studi Akuntansi-FEB UNIPMA.

Indriyanti, M. (2019). The Accuracy of Financial Distress Prediction Models: Empirical Stidy on the World's 25 Biggest Tech Companies in 2015-2016 Forbe's Version. 3rd ICEEBA International Conference on Economics, Education, Business and Accounting. Surabaya: Accounting Department Faculty of Economy State University of Surabaya.

Jayanti, Q. \& Rustiana. (2015). Analisis Tingkat Akurasi Model-Model Prediksi Kebangkrutan Untuk Memprediksi Voluntary Auditor Switching (Studi Pada Perusahaan Manufaktur Yang Terdaftar Di BEI). MODUS Vol.27 (2):87-108. Yogyakarta: Fakultas Ekonomi Universitas Atma Jaya.

Jouzbarkand, M., Aghajani, V., Khodadadi, M. \& Sameni, F. (2012). Creation Bankcruptcy Prediction Model with Using Ohlson and Shirata Models. DOI: 10.7763/IPEDR. V54.1. Iran: Departement of Accounting Islamic Azad University.

Kadir. (2015). Statistika Terapan: Konsep, Contoh dan Analisis Data dengan Program SPSS/Lisrel 
dalam Penelitian Edisi Kedua. Jakarta: PT Rajagrafindo Persada.

Keown, Arthur J., Martin, John D., Petty, J. William., \& Scott, David F. (2011). Manajemen Keuangan Prinsip dan Penerapan. Jakarta: PT Indeks.

Khoiriyah, S. (2019). Analisis Financial Distress, Perbandigan Dan Tingkat Akurasi Menggunakan Model Altman Z-Score, Grover, Springate Dan Zmijewski Untuk Memprediksi Kebangkrutan Pada Perusahaan (Studi Empiris Pada Perusahaan Delisting Di BEI Tahun 20122017). Skripsi. Surakarta: Jurusan Akuntansi Syariah Fakultas Ekonomi dan Bisnis Islam IAIN Surakarta.

Kusuma, R. (2017). Analisis Pengukuran Financial Distress Dengan Model Altman, Springate, Zmijewski, Ohlson, dan Grover Sebagai Early Warning System. Skripsi. Malang: Program Studi Manajemen Fakultas Ekonomi UIN Maulana Malik Ibrahim.

Margaretha, Farah. (2011). Manajemen Keuangan Untuk Manajer Non Keuangan. Jakarta: Penerbit Erlangga.

Meiliawati A. \& Isharijadi (2016). Analisis Perbandingan Model Springate Dan Altman Z Score Terhadap Potensi Financial Distress (Studi
Kasus Pada Perusahaan Sektor Kosmetik Yang Terdaftar Di Bursa Efek Indonesia). Jurnal Akuntansi dan Pendidikan, Volume \%, Nomor 1. Madiun: IKIP PGRI Madiun.

Oz, I.O. \& Yelkenci, T. (2015). The Generalizability of Financial Distress Prediction Models: Evidence from Turkey. Accounting and Management Information Systems Vol. 4, No. 4, pp, 685-703. United States \& Turkey: Central Connecticut State University \& Izmir University of Economics.

Perwira, Vincentus V. Y. (2016). Evaluasi Keakurasian Prediksi Kondisi Bankcrupty. Skripsi. Yogyakarta: Program Studi Akuntansi Fakultas Ekonomi Universitas Sanata Dharma.

Plihal, T., Sponerova, M. \& Sponer, M. (2018). Comparative analysis Of Credit Risk Models In Relatoion To SME Segment. DOI:10.5817/FAI-1-3 No.1. Czech Republic: Faculty of Economics and Administration Department of Finance Masaryk Universuty \& Department of Management Karel Englis College.

Priambodo, D. (2017). Analisis Perbandingan Model Altman, Springate, Grover, dan Smijewski dalam Memprediksi Fnancial Distress. Skripsi. 
Yogyakarta: Program Studi Akuntansi Fakultas Ekonomi Universitas Negeri Yogyakarta.

Romadhona, M.N. (2013). Analisis Perbandingan Kebnagkrutan Model Altman, Model Springate, Dan Model Zmijewski Pada Perusahaan Yang Tergabung Dalam Grup Bakrie Yang Terdaftar Di Bursa Efek Indonesia Periode 2010-2012. Skripsi. Surabaya: Universitas Negeri Surabaya.

Sayari, N. \& Mugan, C. S. (2017). Industry Specific Financial Distress Modeling. $\quad B R Q$ Business Research Quarterly 20, 45-62.

Sondakh, C.A., Murni, S. \& Mandagie, Y. (2014). Analisis Potensi Kebangkrutan Dengan Menggunakan Metode Altman Z-Score, Springate Dan Zmijewski Pada Industri Perdagangan Ritel Yang Terdaftar Di BEI Periode 20092013. Jurnal EMBA Vol.2 No.4. Manado: Jurusan Manajemen Fakultas Ekonomi dan Bisnis Universitas Sam Ratulangi.

Sugiyono, (2016). Metode Penelitian Kuantitatif, Kualitatif, dan $R \& D$. Bandung: Penerbit Alfabeta Bandung.

Utama, B. I., Sudjana, N., \& Nurlaily, F. (2018). Analisis Keakuratan Model Ohlson dalam
Memprediksi Kebangkrutan

(Bankcrupty). Jurnal Administrasi Bisnis (JAB) Vol. 64 No. 2. Malang: Fakultas Ilmu Administrasi Universitas Brawijaya.

Wulandari, V., Nur DP, E. \& Julita. (2014). Analisis Perbandingan Model Altman, Springate, Ohlson, Fulmer, CA-Score dan Zmijewski Dalam Memprediksi Financial Distress (Studi Empiris Pada Perusahaan Food And Beverages Yang Terdaftar Di Bursa Efek Indonesia Periode 2010-2012). JOM FEKON Vol.1 No.2. Pekanbaru: Faculty of Economic Riau University.

Yuliastary, E.C. \& Wirakusuma, M.G. (2014). Analisis Financial Distress dengan Metode Z-Score Altman, Springate, Zmijewski. E-Jurnal Akuntansi Universitas Udayana 6.3. Bali: Fakultas Ekonomi dan Bisnis Universitas Udayana.

Zeynep \& Erdem, (2017). Financial Failure Estimate in BIST Companies with Altman (ZScore) and Springate (S-Score) Models. Journal of Economics and Administrative Sciences, Vol:1, Issue:1,pp 1-14. Istambul: Osmaniye Korkut Ata University.

www.bps.go.id

www.idx.co.id 
www.tribun-bali.com

www.tribunnews.com 